\title{
Article 1. Objective
}

The objective of this Protocol is the fair and equitable sharing of the benefits arising from the utilization of genetic resources, including by appropriate access to genetic resources and by appropriate transfer of relevant technologies, taking into account all rights over those resources and to technologies, and by appropriate funding, thereby contributing to the conservation of biological diversity and the sustainable use of its components

\section{Overview}

The opening provision of the Nagoya Protocol clarifies that fair and equitable sharing of benefits arising from the utilization of genetic resources is the objective - the 'essential goal'1 - of the Protocol. It further indicates three means for its realization - in primis, access to genetic resources, but also technology transfer and funding.

Two notable features of Article 1 are the explicit link established between benefit-sharing and the other two objectives of the CBD - conservation and sustainable use; and the absence of any reference to traditional knowledge, which, however, is a key component of the regime created by the Protocol. The following sections will first introduce the reader to the relation between benefit-sharing and access to genetic resources, highlighting key tensions between CBD Parties underlying the whole text of the Protocol. Second, the missing reference to traditional knowledge will be addressed. Then we will turn to the relevance of the connection between the Protocol's objective and the first and second objectives of the СвD. Finally, the practical and legal functions of Article 1 will be illustrated, to equip the reader to understand references to the objective in other provisions of the Protocol.

1 David Jonas and Thomas Saunders, "The Object and Purpose of a Treaty: Three Interpretative Methods." Vanderbilt Journal of Transnational Law 43 (2010): 565, 567. 
The objective replicates verbatim the third objective of the $\mathrm{CBD}$, which refers prominently to fair and equitable benefit-sharing in its Article 1 (Objectives) ${ }^{2}$ and points to three means of sharing benefits, each underpinned by specific provisions of the Convention: appropriate access to genetic resources; ${ }^{3}$ appropriate transfer of relevant technologies, ${ }^{4}$ including biotechnology; ${ }^{5}$ and appropriate funding. ${ }^{6}$ Among these three means, the Nagoya Protocol emphasizes access, by referring to 'access and benefit-sharing' in its title and devoting two central provisions to it. ${ }^{7}$ Technology transfer and finance are addressed in successive provisions of the Protocol. 8

The preamble confirms that the Protocol aims to implement the third objective of the $\mathrm{CBD},{ }^{9}$ by spelling out the steps for the operationalization of СBD Article 15 on access to genetic resources, ${ }^{10}$ with a view to further supporting the effective implementation of the ABs provisions of the Convention. ${ }^{11}$

2 СвD Article 1 reads: 'The objectives of this Convention, to be pursued in accordance with its relevant provisions, are the conservation of biological diversity, the sustainable use of its components and the fair and equitable sharing of the benefits arising out of the utilization of genetic resources, including by appropriate access to genetic resources and by appropriate transfer of relevant technologies, taking into account all rights over those resources and to technologies, and by appropriate funding,' emphasis added. Tvedt and Young, Beyond Access, op. cit., 5.

3 СвD Article 15.

4 СBD Article 16.

5 СвD Article 19.

6 Addressed in свр Articles 20 and 21. See generally, Glowka, Burhenne-Guilmin and Synge, Guide to the Convention on Biological Diversity, op. cit., 15. It should be noted that the text of Nagoya Protocol Article 1 does not include cross-references to these specific СвD Articles.

7 See this commentary on Articles 6 (Access to Genetic Resources) and 7 (Access to Traditional Knowledge).

8 See this commentary on Articles 23 and 25 respectively. The reference to 'taking into account all rights ... to technologies' in Article 1 foreshadows legal issues related to intellectual property rights on relevant technologies and their bearing on Parties' ability to facilitate technology transfer. This question will be discussed more in detail in this commentary on Article 23.

9 Nagoya Protocol 2nd preambular recital, which reiterates the relevant wording of СвD Article 1 .

10 The latter is specifically recalled in Nagoya Protocol 4th preambular recital.

11 Nagoya Protocol 12th preambular recital. 
The preamble also points to providing legal certainty and promoting equity and fairness in negotiations between users and providers of genetic resources. ${ }^{12}$

Fairness and equity are indeed two critical features of benefit-sharing in international biodiversity law, and part and parcel of the objective of the Protocol. Fairness can be understood as encapsulating both the need for legitimacy (the degree to which rules are made and applied in accordance with what the participants perceive as right process) and for equity or justice (the degree to which the rules satisfy the participants' expectations of justifiable distribution of costs and benefits). ${ }^{13}$ In the latter sense, it introduces notions of reasonableness and a common ethic of the international community through consideration of a broader array of socio-economic factors and a committment in principle to a notion of fair allocation that aims to 'narrow the gap between the haves and have-nots.' ${ }^{14}$

The preamble also serves to clarify that the Protocol is expected more broadly to contribute through fair and equitable benefit-sharing to the achievement of sustainable development. ${ }^{15}$ СвD Parties acknowledge the potential role of ABS to contribute not only to the other objectives of the CBD (conservation and sustainable use), but also to poverty eradication and environmental sustainability more generally, thereby contributing to achieving the Millennium Development Goals. ${ }^{16}$ In addition, reference is made to technology transfer and cooperation, as means of benefit-sharing, that can build research and

\footnotetext{
12 Nagoya Protocol 9-10th preambular recitals.

13 Thomas Franck, Fairness in International Law and Institutions (Oxford: Oxford University Press, 1995), 7.

14 Ibid, 12-13 and 47-80.

15 Braulio Dias, "Preface," op. cit., 1; and discussion in the Conclusions to this commentary, section 2.

16 Nagoya Protocol 7th preambular recital. The Millennium Development Goals were developed by the UN, following consultations among international agencies, as a set of interconnected and mutually reinforcing development goals, accompanied by targets and benchmarks based on the time-bound commitments contained in UN General Assembly, "United Nations Millennium Declaration" (8 September 2000) Un Doc A/REs/55/2. The Millennium Development Goals were then intergovernmentally approved at the $2005 \mathrm{UN}$ Summit, "World Summit Outcome," paragraph 17. The eight Millennium Development Goals are to: eradicate extreme poverty and hunger; achieve universal primary education; promote gender equality and empower women; reduce the mortality rate of children; improve maternal health; combat HIV/AIDS, malaria and other diseases; ensure environmental sustainability; and develop a global partnership for development. See: “Millennium Development Goals and Beyond 2015," un, accessed 30 November 2013, $<$ www.un.org/millenniumgoals/>.
} 
innovation capacity for adding value to genetic resources in developing countries, as an important contribution to sustainable development. ${ }^{17}$

Against this background, the relation between benefit-sharing as the objective of the Protocol and access to genetic resources is not as straightforward as the wording of Article 1 may imply. The preamble in a sibylline formulation simply 'acknowledges the linkage' between the two without any further elaboration. ${ }^{18}$ While it may be intuitive that without access to genetic resources there could be no benefits to share, it has been argued that the obligations to ensure benefit-sharing and to facilitate access to genetic resources under the Convention do not have the same legal force..$^{19}$ In fact, Article 1 represents the compromise ${ }^{20}$ between СвD Parties emphasizing benefit-sharing as the main objective of the Protocol ${ }^{21}$ and those Parties emphasizing access to genetic resources as an additional objective that should have been placed in the Nagoya Protocol on the same footing as benefit-sharing. ${ }^{22}$ Tensions over the

17 Nagoya Protocol 5th preambular recital.

18 Nagoya Protocol 8th preambular recital.

19 See CвD Article 15(2), which requires Parties to 'endeavor to create conditions to facilitate access ... for environmentally sound uses'access' and 15(7), which requires Parties to 'take legislative, administrative or policy measures ... with the aim of sharing in a fair and equitable way the ... benefits arising from the commercial use and other utilization of genetic resources.' See comments by Morgera and Tsioumani, "Evolution of Benefit-Sharing," op. cit., 154.

ENB, "Summary of Resumed Ninth Meeting of the Ad Hoc Open-ended Working Group on Access and Benefit-sharing: 10-16 July 2010," Vol. 9 No. 527, 19 July 2010.

21 The current formulation emerged from the resumed ninth meeting of the CBD Working Group on ABS: "Draft Protocol on Access to Genetic Resources and the Fair and Equitable Sharing of Benefits Arising from their Utilization to the Convention on Biological Diversity" in "Report of the second part of the ninth meeting of the Ad Hoc Open-ended Working Group on Access and Benefit-sharing" (28 July 2010) un Doc UneP/CBD/ COP/10/5/Add.4, Annex (hereinafter, Montreal I Draft), on the basis of an initial formulation in the Cali Draft, which was limited to declaring benefit-sharing the objective of the Protocol and making a link with the other two objectives of the свD. In the Cali Draft, draft article 1 read: 'The objective of this Protocol is to ensure the fair and equitable sharing of the benefits arising from the utilization of genetic resources, contributing to the conservation of biological diversity and the sustainable use of its components.'

Note the EU proposal to this end in свр Working Group on Aвs, "Report of the first part of the ninth meeting," UNEP/CBD/WG-ABS/9/3, 19 'the facilitation of access to genetic resources and the fair and equitable sharing of the benefits arising from the utilization of genetic resources that were obtained after the entry into force of this Protocol, also contributing to the conservation of biological diversity and the sustainable use of its components.' 
appropriate framing of the objective of the Protocol had in fact emerged from the inception of its negotiating mandate. On the one hand, without mentioning access, the Johannesburg Plan of Implementation called for:

negotiat[ing] within the framework of the Convention on Biological Diversity, bearing in mind the Bonn Guidelines, an international regime to promote and safeguard the fair and equitable sharing of benefits arising out of the utilization of genetic resources. ${ }^{23}$

On the other hand, the mandate agreed upon by the CBD COP clearly mentioned both:

The COP ... Decides to mandate the Ad Hoc Open-ended Working Group on Access and Benefit- sharing with the collaboration of the Ad Hoc Open ended Inter-Sessional Working Group on Article 8(j) and Related Provisions, ensuring the participation of indigenous and local communities, non-governmental organizations, industry and scientific and academic institutions, as well as intergovernmental organizations, to elaborate and negotiate an international regime on access to genetic resources and benefit-sharing with the aim of adopting an instrument/instruments to effectively implement the provisions in Article 15 and Article 8(j) of the Convention and the three objectives of the Convention. ${ }^{24}$

Overall, Article 1 confirms that fair and equitable benefit-sharing is the ultimate objective of the implementing measures to be adopted by the Protocol Parties. However, the underlying tension in the relationship between the 'access' and 'benefit-sharing' pillars of the Protocol is reflected in the various compromises reached between those CBD Parties mostly characterizing themselves as user countries and those characterizing themselves as provider countries. ${ }^{25}$ It should be preliminarily noted that access, benefit-sharing and compliance are the three constitutive elements of the political deal behind the Protocol adoption - the so-called 'ABC of ABS. ${ }^{26}$ Ultimately, the actual balance struck between access and benefit-sharing is to be determined on the basis of

23 Johannesburg Plan of Implementation, paragraph 44(o).

24 СвD Decision 7/19, section D, paragraph 1, emphasis added.

25 СвD Decision 7/19, section D, 16th preambular recital. See Introduction to this commentary, section 1.3 .

26 СвD Friends of the Co-Chairs Meeting on access and benefit-sharing, "Paper on selected key issues submitted by the Co-Chairs" (26-29 January 2010), accessed 30 November 
the more specific provisions contained in the Nagoya Protocol, ${ }^{27}$ which are to be interpreted in the light of the objective of realizing fairness and equity in benefit-sharing.

Article 1 does not mention benefit-sharing in relation to traditional knowledge, in line with the Protocol's own title ('Access to Genetic Resources and the Fair and Equitable Sharing of Benefits from Their Utilization'). Nevertheless, as the Св D СОР mandate for the Protocol negotiations clearly indicated, СвD Parties had come to an understanding that access and benefit-sharing would also apply to traditional knowledge associated with genetic resources, based on a combined reading of the former does not mention traditional knowledge and the latter does not mention genetic resources. ${ }^{29}$ As the object and purpose of a treaty are also to be deduced from its preamble and other programmatic articles, ${ }^{30}$ attention should be drawn to several substantive provisions of the Protocol that are wholly or significantly devoted to traditional knowledge associated with genetic resources. ${ }^{31}$ It can therefore be asserted that benefit-sharing related to the use of traditional knowledge associated with genetic resources ${ }^{32}$ is part and parcel of the objective of the Protocol. This interpretation appears confirmed by the express provision on the Protocol scope, which extends to

2013, <www.cbd.int/doc/?meeting=ABS-FOCC-01>, paragraph 3. See also: ENB 9/527, "Summary of the Resumed Ninth Meeting of the Working Group on ABs," 14.

27 See in particular this commentary on Articles 5-6, 15 and 17-18.

28 As confirmed in Nagoya Protocol 21st preambular recital, which recalls the 'relevance' of Свр Article 8(j) 'as it relates to traditional knowledge associated with genetic resources,' emphasis added. The Bonn Guidelines already foreshadowed this development, by stating: 'These Guidelines may serve as inputs when developing and drafting legislative, administrative or policy measures on access and benefit-sharing with particular reference to provisions under Articles 8(j), 10(c), 15, 16 and 19 [of the СвD]; and contracts and other arrangements under mutually agreed terms for access and benefit-sharing': Bonn Guidelines, paragraph 1, emphasis added.

29 As discussed in the Introduction to this commentary, sections 1.3 and 3. See also this commentary on Article 7.

$30 \quad$ E.g. Richard Gardiner, Treaty Interpretation (Oxford: Oxford University Press, 2008), 196.

31 See commentary on Article 5, section 4 and Articles 7, 12 and 16.

32 Unless otherwise specified, the rest of the commentary will always refer to 'traditional knowledge' as 'associated with genetic resources.' 
traditional knowledge. ${ }^{33}$ The objective of sharing in a fair and equitable manner benefits arising from the use of traditional knowledge with indigenous and local communities needs thus to be taken into account in the interpretation of the whole Protocol. In this connection, the reference to 'taking into account all rights over those resources' points to the question of the indigenous peoples' and local communities' rights over genetic resources ${ }^{34}$ and also their rights related to traditional technologies. ${ }^{35}$

\section{$4 \quad$ Links with Conservation and Sustainable Use}

The third objective of the CBD as the objective of the Protocol is not to be pursued in isolation from the broader framework established by the CвD. Notably, the objective of the Nagoya Protocol is clearly and expressly linked to the other two objectives of the CBD, as it specifies that benefit-sharing is seen as a 'contribution' to the conservation of biological diversity and the sustainable use of its components. ${ }^{36}$ This seeks to ensure a coherent interpretation and integrative implementation of the СвD three objectives in the context of the Nagoya Protocol. ${ }^{37}$ It encapsulates the idea that ABS can function as a source of funding or incentive for, or otherwise contribute to, the achievement of the other two objectives of the Convention. ${ }^{38}$ This idea is more concretely pursued in several operational provisions. ${ }^{39}$

'Sustainable use' is defined by the свD as 'the use of components of biological diversity in a way and at a rate that does not lead to the long-term decline

33 See commentary on Article 3, sections 1-2.

34 Nagoya Protocol Articles 5(2) and 6(2). We are grateful to Krystyna Swiderska for drawing our attention to this point, which will be discussed in detail in the commentary on Articles 5, section 3 and 6, section 4.

35 See commentary on Article 23. See also Ajit Bhalla, Dilmus James and Yvette Stevens, eds., Blending of New and Traditional Technologies: Case Studies (Geneva: ILO, 1984).

$36 \quad$ As already highlighted in the Bonn Guidelines, paragraph 48.

37 Morgera and Tsioumani, "Evolution of Benefit-Sharing," op. cit., 173.

38 Nagoya Protocol 7th preambular recital. See also the "Strategy for resource mobilisation in support of the achievement of the Convention's three objectives for the period 20082015" in свD Decision 9/11, "Review of implementation of Articles 20 and 21" (9 October 2008) UN Doc UNEP/CBD/COP/9/29, Annex, which includes a goal on enhancing implementation of ABs initiatives, considering them a tool for generating financial returns to support conservation and sustainable use initiatives in provider countries, Goal 7.

39 See commentary on Article 5, section 6, Article 8, section 2, Article 9, section 2, Article 10 , section 4, Article 12, section 4, Article 21, section 3, Article 22, and Article 23, section 3. 
of biological diversity, thereby maintaining its potential to meet the needs and aspirations of present and future generations. ${ }^{40}$ There is, however, no definition of 'conservation' as such in the Convention but rather a clarification of the distinction between ex situ and in situ conservation as respectively 'outside natural habitats' and in genetic resources' 'natural surroundings' or 'in the surroundings where they have developed their distinctive properties.' ${ }^{41}$ Thus, to better understand how the Nagoya Protocol is expected to contribute to conservation and sustainable use it is necessary to make reference to relevant provisions in the $\mathrm{CBD}$, namely its Articles $8-10$. On that basis, benefit-sharing under the Protocol can be expected to contribute to, inter alia, the selection and management of protected areas and species, the restoration of degraded ecosystems and the recovery of threatened species, the protection and promotion of traditional knowledge, the creation of measures and/or facilities for ex situ conservation, the support towards sustainable customary use and remedial action by local communities. ${ }^{42}$ Notably, both СвD Articles 8 and 10 also contain references to the central role of indigenous and local communities in contributing to conservation and sustainable use..$^{43} \mathrm{~A}$ combined reading of Article 8(j) and 10(c) in particular leads to connecting the aim of fair and equitable benefit-sharing with the use of traditional knowledge contributing to in situ conservation and also with communities' sustainable traditional use of biological resources. ${ }^{44}$

It should also be noted that the Nagoya Protocol seeks to contribute to the first and second objectives of the Св D by calling upon Parties to promote and encourage research activities contributing to conservation and sustainable usd of biodiversity, particularly in developing countries. ${ }^{45}$ Furthermore, the

$40 \quad$ CBD Article 2.

41 СBD Article 2.

42 But also: control of living modified organisms (LMOs) and invasive alien species, and cooperation between authorities and the private sector on sustainable use. For a discussion on how inter-State benefit-sharing can reach indigenous and local communities, see Morgera and Tsioumani, "Evolution of Benefit-Sharing," op. cit., 155-158. For a discussion of the potential contribution of ABs to development, see Reid et al., Biodiversity Prospecting, op. cit.; and Rachel Wynberg and Sarah A. Laird, "Bioprospecting, Access and Benefit Sharing: Revisiting the 'Grand Bargain,'” in Wynberg, Schroeder and Chennells, Indigenous Peoples, Consent and Benefit Sharing, op. cit., 69.

43 свD Articles 8(j) and 10(c). We are grateful to Krystina Swiderska for drawing our attention to this point.

44 Morgera and Tsioumani, "Evolution of Benefit-Sharing”, op. cit., 159.

45 Nagoya Protocol Article 8(a), which expands on СвD Article 12: see this commentary on Article 8, section 2. 
Protocol foresees not only a contribution of ABS to biodiversity conservation, but also to environmental protection more broadly conceived. In fact, its preamble notes the importance of genetic resources also for the mitigation of and adaptation to climate change. ${ }^{46}$

The importance of the Protocol's support for a coherent implementation of the three СвD objectives ${ }^{47}$ should not be underestimated. With two new protocols and an ever-growing range of decisions adopted by the СвD СоР, States' obligations and commitments have expanded considerably under the Convention at the risk of substantive and procedural fragmentation. This has become particularly visible in the context of the Cartagena Protocol: ${ }^{48}$ in many respects, the biosafety regime has developed into an independent sub-process that has little, if any, link with the СвD. This development can be explained and arguably justified on the basis of the very specific and technical nature of the Cartagena Protocol's subject matter. ${ }^{49}$ On the other hand, the negotiators of the Nagoya Protocol have specifically arranged for keeping the Protocol in close relation with the $\mathrm{CBD}$, through substantive provisions that expressly link benefit-sharing to the conservation of biological diversity and the sustainable use of its components, ${ }^{50}$ as well as the institutional arrangement to hold meetings of its Parties in conjunction with the meetings of свр Parties. ${ }^{51}$

\section{$5 \quad$ Legal and Practical Functions}

According to general international law, Article 1 seeks to clarify the 'object and purpose' of the Protocol as the chief criterion for the interpretation of the whole treaty. ${ }^{52}$ As explained above, a correct understanding of the scope of the

46 Nagoya Protocol 14th preambular recital. On the links between genetic resources and climate change, see e.g. FAO Commission on Genetic Resources for Food and Agriculture (CGRFA), "Roadmap on climate change and genetic resources for food and agriculture" FAO Doc CGRFA-14/13/5 (2013); and "Selected processes and initiatives on climate change of relevance to genetic resources for food and agriculture" FAO Doc CGRFA-14/13/Inf.10 (2013).

47 See this commentary on Articles 1, section 4; 5, section 6; 9, section 2 and 10, section 4.

48 Cartagena Protocol on Biosafety (Montreal, 29 January 2000, in force 11 September 2003) 2226 UNTS 208.

49 Morgera and Tsioumani, "Yesterday, Today, and Tomorrow," op. cit., 38.

$50 \quad$ See fn. 39 above.

51 Nagoya Protocol Article 26(6): see this commentary on Article 26, section 3.

52 vCLT Article 31(1). See Jonas and Saunders, "The Object and Purpose of a Treaty," op. cit., $577-582$. 
Protocol necessarily requires reading Article 1 together with the Protocol's preamble and other programmatic provisions.

Where the meaning imparted by the text of a treaty itself is equivocal or inconclusive or where confirmation of the correctness of the reading of the text is desired, the object and purpose of the treaty as a whole may shed some light. ${ }^{53}$ While the object and purpose cannot override the ordinary meaning of the text of a treaty, they can be interpreted as 'modifiers' of the ordinary meaning. ${ }^{54}$ Thus, the object and purpose of a treaty can facilitate its evolutive interpretation. ${ }^{55}$ In addition, the object and purpose of a treaty can be used as a means to reconcile divergences in the text of the Protocol in two or more of its authenticated languages, when no text has been agreed to prevail in case of divergence and the difference in meaning cannot be resolved by applying the other general rules on treaty interpretation, as long as the chosen meaning is that which best reconciles the texts. ${ }^{56}$

The interpretative relevance of the object and purpose of the treaty is particularly significant in the context of the often open-ended or heavily qualified language used in the Nagoya Protocol. In that regard, it is of the utmost importance that its object and purpose (i.e. ensuring the fair and equitable sharing of benefits arising from genetic resources and/or traditional knowledge among and within States, with a view to contributing to conservation and sustainable use) guide Parties in unilaterally implementing the Protocol where they are allowed a wide margin of discretion, and collectively ${ }^{57}$ in further developing certain provisions of the Protocol that require further negotiations. ${ }^{58}$ In both regards, the object and purpose of a treaty can serve to 'maintain the balance of rights and obligations created by the treaty. 59 This is particularly - but not exclusively - the case in Protocol operative provisions that specifically refer to the 'objective' of the Protocol. For instance, the objective serves as a substantive limit to the Parties' negotiating and legislative discretion in the development and implementation of future 'specialized ABS instruments,' as well as a substantive limit to the interpretative discretion of Parties in achieving

53 vClt Article 33. See ICJ, Territorial Dispute (Libyan Arab Jamahiriya v. Chad), Judgment (3 February 1994), paragraph 41.

54 Gardiner, Treaty Interpretation, op. cit., 190 and 192.

55 Boyle and Chinkin, Making of International Law, op. cit., 246.

$56 \quad$ vCLT Article 33(4). See Gardiner, Treaty Interpretation, op. cit., 193.

57 Nagoya Protocol Article 26(4)(a): see this commentary on Article 26, section 2.

58 See for example this commentary on Articles 10 and 30.

59 Villiger, "1969 Vienna Convention on the Law of Treaties," op. cit., 118. 
mutual supportiveness between the Protocol and other relevant international instruments. ${ }^{60}$ In addition, it serves as an aim for transboundary cooperation. ${ }^{61}$

Furthermore, this Article is relevant in relation to the international obligations of States signatories to the Protocol. Signatories of an international treaty are obliged not to defeat the object and purpose of a treaty prior to its entry into force, unless these States afterwards explicitly express their intention not to ratify it. ${ }^{62}$ This general rule appears particularly significant at the time of writing, as the Protocol is not yet in force, ${ }^{63}$ but a significant number of signatories are developing domestic ABS frameworks and undertaking other activities, such as providing capacity building ${ }^{64}$ on ABS on the ground. ${ }^{65}$

6o See this commentary on Article 4, section 3.

61 See this commentary on Article 11. Interpretative questions arise however from the fact that the provision on transboundary cooperation in relation to genetic resources just refers to 'with a view to implementing the Protocol' - Nagoya Protocol Article 11(1) whereas the provision on transboundary cooperation in relation to traditional knowledge specifically refers to 'implementing the objective of this Protocol' - Nagoya Protocol Article 11(2), emphasis added - even if Nagoya Protocol Article 1 does not mention 'traditional knowledge.' For completeness' sake, Nagoya Protocol Article 1 is also the object, among others, of awareness-raising obligations: Article 21(a). See this commentary on Article 21.

62 VCLT Article 18 reads: 'A State is obliged to refrain from acts which would defeat the object and purpose of a treaty when: ( $a$ ) it has signed the treaty or has exchanged instruments constituting the treaty subject to ratification, acceptance or approval, until it shall have made its intention clear not to become a Party to the treaty; or $(b)$ it has expressed its consent to be bound by the treaty, pending the entry into force of the treaty and provided that such entry into force is not unduly delayed.' It should be noted, however, that 'the extent of [such an] interim obligation has never been conclusively defined': Jonas and Saunders, "The Object and Purpose of a Treaty," op. cit., 572-572 and more generally 594-608.

63 At the time of writing the Protocol had 26 ratifications and 92 signatures: see "Status of Signature, and Ratification, Accession, Approval and Acceptance," свD, accessed 30 November 2013, <www.cbd.int/abs/nagoya-protocol/signatories/default.shtml $>$.

64 See this commentary on Article 22.

65 Свр Executive Secretary, "Progress report on the Nagoya Protocol on Access to Genetic Resources and the Fair and Equitable Sharing of Benefits Arising from their Utilization and related developments" (7 September 2012) Un Doc UNEP/СвD/COP/11/11 and ADD.1. 